\title{
Author Correction: Computational tools for genomic data de-identification: facilitating data protection law compliance
}

\author{
Alexander Bernier, Hanshi Liu \& Bartha Maria Knoppers (i)
}

Correction to: Nature Communications https://doi.org/10.1038/s41467-021-27219-2, published online 29 November 2021.

The original version of this Article listed the wrong reference in the first position in the Reference list. The original reference in the first position read as '1. Greenleaf, G. Jamaica adopts a post-GDPR Data Privacy Law. Priv. Laws Int. Bus. Rep. 1, 3-5 (2021).' The correct reference is '1. Greenleaf, G. Global Data Privacy Laws 2021: Despite COVID Delays, 145 Laws Show GDPR Dominance. Priv. Laws Int. Bus. Rep. 1, 3-5 (2021).'

This has been corrected in both the PDF and HTML version of the Article.

Published online: 13 January 2022

\footnotetext{
(c) Open Access This article is licensed under a Creative Commons Attribution 4.0 International License, which permits use, sharing, adaptation, distribution and reproduction in any medium or format, as long as you give appropriate credit to the original author(s) and the source, provide a link to the Creative Commons license, and indicate if changes were made. The images or other third party material in this article are included in the article's Creative Commons license, unless indicated otherwise in a credit line to the material. If material is not included in the article's Creative Commons license and your intended use is not permitted by statutory regulation or exceeds the permitted use, you will need to obtain permission directly from the copyright holder. To view a copy of this license, visit http://creativecommons.org/licenses/by/4.0/.
}

(c) The Author(s) 2022 